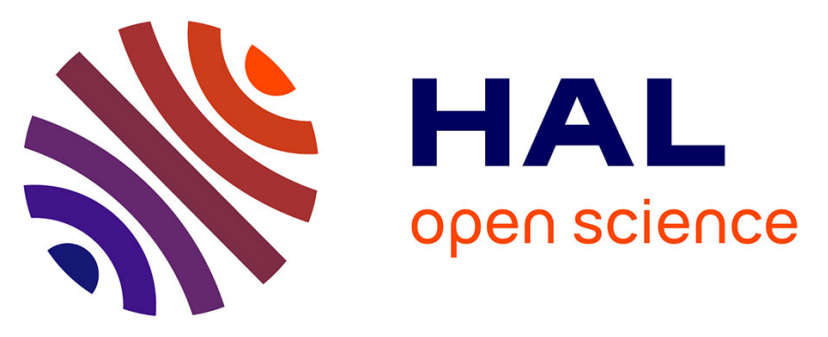

\title{
Benzimidazolium sulfonate ligand precursors and application in ruthenium-catalyzed aromatic amine alkylation with alcohols
}

Nazan Kaloglu, İsmail Özdemir, Nevin Gürbüz, Mathieu Achard, Christian Bruneau

\section{To cite this version:}

Nazan Kaloglu, İsmail Özdemir, Nevin Gürbüz, Mathieu Achard, Christian Bruneau. Benzimidazolium sulfonate ligand precursors and application in ruthenium-catalyzed aromatic amine alkylation with alcohols. Catalysis Communications, 2016, 74, pp.33-38. 10.1016/j.catcom.2015.10.028 . hal01263044

HAL Id: hal-01263044

https://hal-univ-rennes1.archives-ouvertes.fr/hal-01263044

Submitted on 28 Jan 2016

HAL is a multi-disciplinary open access archive for the deposit and dissemination of scientific research documents, whether they are published or not. The documents may come from teaching and research institutions in France or abroad, or from public or private research centers.
L'archive ouverte pluridisciplinaire HAL, est destinée au dépôt et à la diffusion de documents scientifiques de niveau recherche, publiés ou non, émanant des établissements d'enseignement et de recherche français ou étrangers, des laboratoires publics ou privés. 
Benzimidazolium sulfonate ligand precursors and application in ruthenium-catalyzed aromatic amine alkylation with alcohols

Nazan Kaloglu, ${ }^{\mathrm{a}}$ Ismail Özdemir, ${ }^{\mathrm{a}}$ Nevin Gürbüz, ${ }^{\mathrm{a}}$ Mathieu Achard, ${ }^{\mathrm{b}}$ Christian Bruneau ${ }^{\text {b* }}$

${ }^{a}$ Inönü University, Catalysis Research and Application Center, 44280, Malatya, Turkey

${ }^{\mathrm{b}}$ Institut des Sciences Chimiques de Rennes, UMR 6226, Organometallics: Materials and Catalysis, Centre for Catalysis and Green Chemistry, Campus de Beaulieu, 35042 Rennes

Cedex, France

*Corresponding author: e-mail address: christian.bruneau@univ-rennes1.fr 


\section{ABSTRACT}

New benzimidazolium sulfonate salts have been prepared and fully characterized. They have been associated in situ with $\left[\mathrm{RuCl}_{2}(p \text {-cymene })\right]_{2}$ to generate efficient catalytic systems operating at $120{ }^{\circ} \mathrm{C}$ under neat conditions in the presence of potassium tert-butylate for selective $N$-alkylation of primary aromatic amines into secondary amines.

Keywords: Benzimidazolium sulfonates, ruthenium catalysis, $N$-alkylation, hydrogen borrowing 


\section{Introduction}

Amines constitute a class of organic compounds with a wide range of applications in chemical industry ranging from ammonia, produced in million ton scale, to fine chemicals with biological properties [1]. In this context, the creation of $\mathrm{C}-\mathrm{N}$ bonds from primary and secondary amines has been investigated for a long time and more recently using the hydrogen borrowing process starting from alcohol as alkylating agent [2-6]. This methodology offers advantages in terms of atom economy and clean reaction over other methods based on organic or organometallic coupling reactions, as only water is formed as byproduct. $\mathrm{N}$-Alkylation of aromatic amines has been mostly carried out with iridium catalyst precursors such as $\left[\mathrm{Cp} * \mathrm{IrCl}_{2}\right]_{2}$ in the presence of a carbonate or hydrogenocarbonate as mineral base in refluxing toluene. Intermolecular reaction with alcohols [7] and cyclization with diols [8] have thus been successfully achieved. $N$-alkylation of anilines with iridium catalysts has also been carried out without base additive in water in the presence of $\left[\mathrm{Cp} * \mathrm{IrI}_{2}\right]_{2}$ [9] or in neat conditions with dicationic catalysts $[10,11]$. Catalytic systems based on ruthenium precursors have proved to be also efficient for aniline $N$-alkylation. Initial results were obtained using $\mathrm{RuCl}_{2}\left(\mathrm{PPh}_{3}\right)_{3}$ or $\mathrm{RuCl}_{3} \cdot \mathrm{XH}_{2} \mathrm{O}$ in the presence of phosphine without additional base but at high temperature $\left(180^{\circ} \mathrm{C}\right)$ with or without a solvent, leading to substituted secondary and tertiary anilines [12], $N$-aryl-substituted cyclic amines [13], and heterocycles [14]. Then, new catalysts were designed in order to introduce milder conditions, especially lower temperature conditions or lower amounts of base. In the iridium series, this was done by implementation of bidentate $(\mathrm{C}, \mathrm{N}),(\mathrm{P}, \mathrm{N})$ and tridentate $(\mathrm{P}, \mathrm{N}, \mathrm{P})$ ligands, which allowed alkylating aniline below $100{ }^{\circ} \mathrm{C}$ at low catalyst loading with ${ }^{t} \mathrm{BuOK}$ or $\mathrm{CsOH}$ as base [15, 16]. Phosphinesulfonate ligands were also introduced on $\mathrm{Cp} * \operatorname{Ir}(\mathrm{III})$ complexes to achieve the double $\mathrm{N}$ alkylation of primary aniline derivatives with pentanediols [17]. $\mathrm{N}$-Heterocyclic carbene ligands including chelating ones [18-20] were also used with success. The same strategy was applied to ruthenium catalysts and tridentate nitrogen ligands, $(\mathrm{N}, \mathrm{N}, \mathrm{N})$ and $(\mathrm{P}, \mathrm{N}, \mathrm{P})$ pincer ligands were introduced to ruthenium(II) centers but the catalytic $N$-alkylation of aniline still required high temperature [21]. Tridentate $(\mathrm{N}, \mathrm{N}, \mathrm{C})$ [22] and tetradentate $(\mathrm{N}, \mathrm{N}, \mathrm{N}, \mathrm{N})$ [23] ligands provided efficient catalysts able to operate at $100-110{ }^{\circ} \mathrm{C}$ in the presence of a base. More simple ruthenium precursors such as $\left[\mathrm{Ru}\left(\mathrm{Cl}_{2}(\mathrm{cod})\right]_{\mathrm{n}} / 1,3,5\right.$-triaza-7-phosphaadamantane (PTA),[24] [ $\left.\mathrm{RuCl}\left(\mathrm{PPh}_{3}\right)(\mathrm{MeCN})_{3}\right]\left[\mathrm{BPh}_{4}\right]$ [25] or the in situ generated system based on $\left[\mathrm{RuCl}_{2}(p \text {-cymene) }]_{2}\right.$ and diphosphine ligand were found efficient for the $\mathrm{N}$-alkylation of aniline with catalytic amounts of base [26]. However, only scarce examples of ruthenium 
complexes bearing a $N$-heterocyclic carbene ligand have been investigated in $\mathrm{N}$-alkylation of aromatic amines by alcohols [27]. To our knowledge, $\mathrm{RuX}_{2}(\mathrm{NHC})(p$-cymene $)(\mathrm{X}=\mathrm{Cl}, \mathrm{I})$ complexes have revealed good catalytic activity in the reaction of primary aliphatic amines with primary alcohols to form amides but no $\mathrm{N}$-alkylation products were formed [28]. Based on the ability of the basic sulfonate group to transfer protons and generate water-soluble species [29], we decided to prepare new $N$-heterocyclic carbene sulfonate ligands constructed on the benzimidazole core, and evaluate their activity in the $\mathrm{N}$-alkylation of aniline and 2-aminopyridine in the presence of ruthenium catalysts.

\section{Experimental}

\subsection{Preparation of benzimidazolium sulfonates}

The zwitterionic carbene precursors L1-L10 were obtained in a three step procedure according to Scheme 1 . The $N$-alkyl or $N$-benzyl benzimidazole was first prepared by deprotonation of benzimidazole by $\mathrm{NaH}$ in THF at room temperature for $1 \mathrm{~h}$. The resulting sodium benzimidazolate was reacted with the appropriate alkyl or benzyl halide in refluxing THF during 24 h. The resulting $N$-alkyl or $N$-benzyl-benzimidazole was isolated and purified as a white solid. 1-Substituted benzimidazole and 1,3-propanesultone were then dissolved in acetonitrile and refluxed during $72 \mathrm{~h}$. The benzimidazole sulfonate salts L1-L10 were isolated as solids in good to excellent yields.

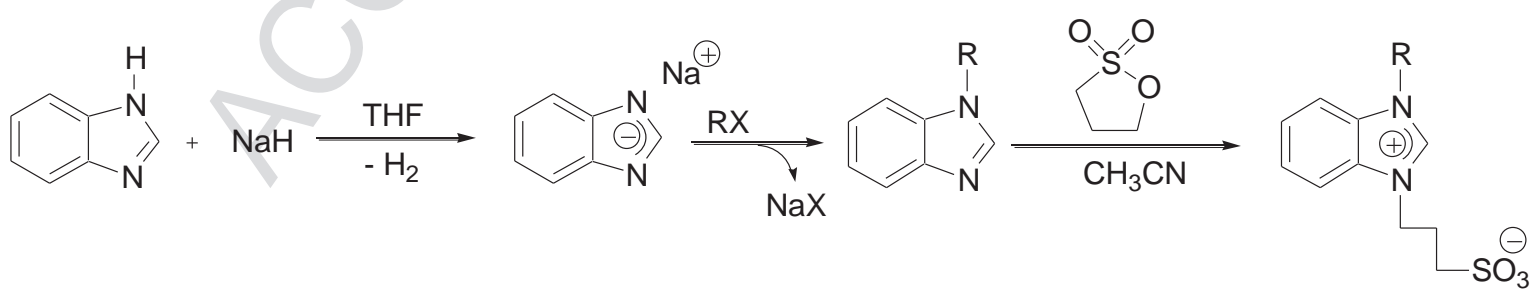

Scheme 1. Synthesis of benzimidazolium sulfonate salts L1-L10

\subsection{Catalytic reactions}

The alcohol derivative $(1.6 \mathrm{mmol})$ was added to a stirred solution of aromatic amine $(1 \mathrm{mmol})$ in a Schlenk tube. Subsequently, ${ }^{t} \mathrm{BuOK}$ (1 mmol), the preligand (L) (1 mol\%) and $\left[\mathrm{RuCl}_{2}(p \text {-cymene })\right]_{2}(0.5 \mathrm{~mol} \%)$ were added and the sealed Schlenk tube was stirred at $120{ }^{\circ} \mathrm{C}$ for $24 \mathrm{~h}$. The crude mixture was collected by addition of $\mathrm{CH}_{2} \mathrm{Cl}_{2}(2 \mathrm{ml})$ for GC analysis, and 
the product was then purified by column chromatography (petroleum ether/ $\mathrm{Et}_{2} \mathrm{O}$ or EtOAc) to afford the pure secondary amine.

\section{Results and discussion}

\subsection{Preparation of benzimidazolium sulfonate salts}

A library of 10 benzimidazolium sulfonate salts L1-L10 has been prepared (Scheme 2). Each of them is equipped with a 1-n-propylsulfonate group linked to one nitrogen atom. The other nitrogen atom is substituted either by an aliphatic ether or an acetal functionality, or a benzylic group diversely substituted on the phenyl ring. The acetal groups are in principle stable in basic conditions and the oxygen atoms might be useful for hydrogen bonding or transfer. As far as the phenyl groups are concerned it has been previously shown that they can easily substitute a coordinated p-cymene ligand on a ruthenium(II) center upon thermal treatment [30]. 
<smiles></smiles>

L1<smiles></smiles>

L2<smiles></smiles>

L3<smiles></smiles>

L4<smiles></smiles>

L5<smiles></smiles><smiles></smiles>

L6

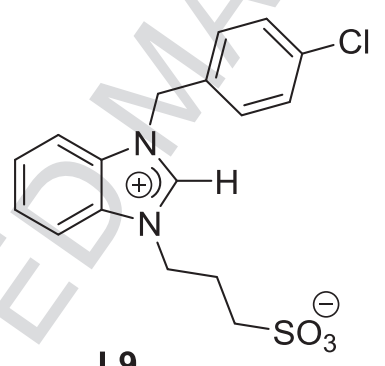

L9

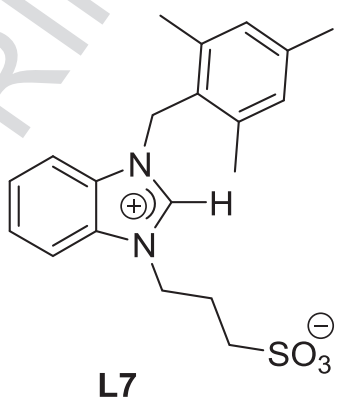

L7

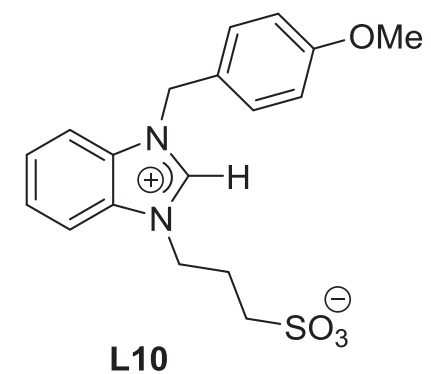

Scheme 2 Library of benzimidazolium sulfonates

L1-L10 are soluble in water and protic solvents; they were characterized by ${ }^{1} \mathrm{H}$ and ${ }^{13} \mathrm{C}$ NMR, and gave satisfactory elemental analysis. The benzimidazolium fragment showed characteristic $\mathrm{C}(2)-H$ proton chemical shift at 8.86-9.64 ppm associated to the ${ }^{13} \mathrm{C}$ NMR chemical shift of the C(2) carbon atom deshielded at 140-150 ppm (Table A.1). These chemical shifts are typical of all types of benzimidazolium salts including less functionalized ones. The ${ }^{1} \mathrm{H}$ NMR spectra of the linear $n$-propylsulfonate group is clearly identified by a triplet at 4.5-4.8 ppm for $\mathrm{NCH}_{2}$, another triplet at 2.8-3.0 ppm for $\mathrm{CH}_{2} \mathrm{SO}_{3}$, and a pentuplet centered at $2.4 \mathrm{ppm}$ for the internal $\mathrm{CH}_{2}$ group, all coupling constants being close to $7 \mathrm{~Hz}$. 


\subsection{Catalytic application in alkylation of aniline derivatives with alcohols}

In order to evaluate the potential of carbene sulfonate ligands in hydrogen borrowing processes, we associated these ligands with $\left[\operatorname{RuCl}_{2}(p \text {-cymene })\right]_{2}$, a very established precursor of efficient catalytic systems for this type of reaction [26], and studied their ability to achieve benzylation of aniline with benzyl alcohol as a model reaction. Aniline being a weak base $(\mathrm{pKa}=4.6)$, the benzimidazolium sulfonate salts $\mathbf{L 1 - L 1 0}$ were deprotonated by ${ }^{t} \mathrm{BuOK}$ in the presence of the ruthenium source to generate a catalytic system in situ.

The reaction were carried out at $120{ }^{\circ} \mathrm{C}$ for $24 \mathrm{~h}$ in neat conditions with $0.5 \mathrm{~mol} \%$ of ruthenium dimer and $1 \mathrm{~mol} \%$ of benzimidazolium sulfonate in the presence of a slight excess of benzyl alcohol. The results presented in Table A.1 show that all the ligand precursors led to high conversion with the amine $\mathbf{3 a}$ as the major product, the imine $\mathbf{4 a}$ being detected only as traces amount in some cases.

The influence of various parameters was then studied using the ligand precursor $\mathbf{L} 1$ (Table 1). Up to $90 \%$ conversion were obtained with $15 \mathrm{~mol} \%$ of $t \mathrm{BuOK}$ (entries 1-4) and full conversion with high selectivity in favor of the amine could be obtained only when the ligand was added and a stoichiometric amount of ${ }^{t} \mathrm{BuOK}$ was used (entries $6,7,13$ ), which was in accordance with many previous results starting from aniline, and indicated that this strong base was not only useful for carbene generation but also accelerated imine hydrogenation (entries 5, 6). It is noteworthy that in the absence of base, a 2,6-bis(di-tertbutylphosphinomethyl)pyridine pincer ruthenium complex led to the selective formation of imines from alcohols and aliphatic amines [31]. Decreasing the reaction temperature or the catalyst loading had a detrimental effect on both conversion and selectivity towards amine formation. It is also worth mentioning that the benzylation tolerated water as solvent (entry 12) and was also efficiently performed in toluene with high selectivity (entry 13). An excess of alcohol (1.6 equivalent) was required to achieve complete conversion of aniline. Indeed, potassium benzoate was formed as an undesired side product of this reaction resulting from Tishchenko or Cannizzaro disproportionation reaction from the intermediate benzaldehyde in the presence of ${ }^{t} \mathrm{BuOK}$ and water arising from imine formation. It is noteworthy that in the presence of the benzimidazolium salt and base but in the absence of ruthenium precursor, no reaction took place (entry 15). Only 24\% conversion was obtained in the presence of the metallic precursor and proligand showing the important role of ${ }^{t} \mathrm{BuOK}$ in this catalytic system (entry 16). $72 \%$ conversion with an amine/imine ratio of $90 / 10$ was observed when the 
ruthenium dimer and the base were used in the absence of ligand (entry 14) confirming the preponderant role of the base and the ligand for efficient alkylation of aromatic amines [32].

Table 1. Benzylation of aniline 1a with benzyl alcohol 2a
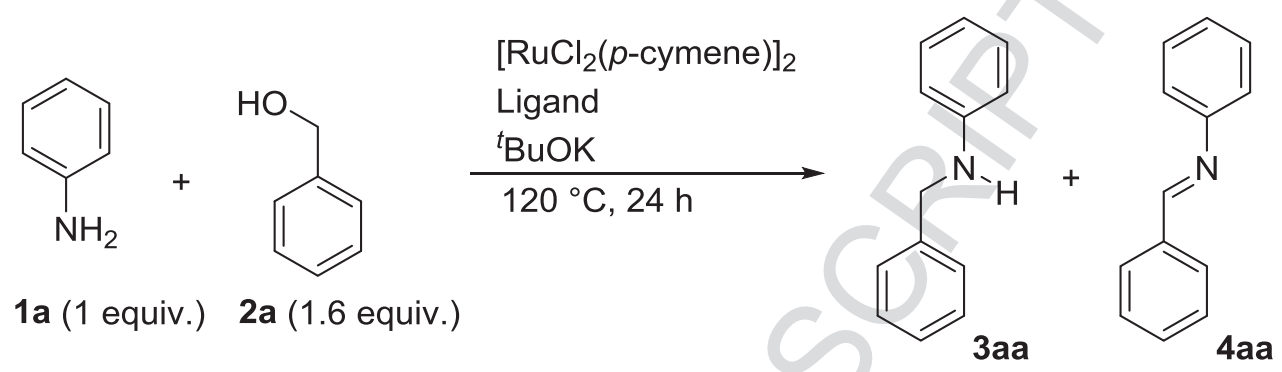

\begin{tabular}{|c|c|c|c|c|c|c|}
\hline Entry & Ruthenium precursor (mol\%) & $\begin{array}{l}\text { Préligand } \\
\text { (mol\%) }\end{array}$ & $\begin{array}{c}{ }^{t} \mathrm{BuOK} \\
(\mathrm{mol} \%)\end{array}$ & $\begin{array}{l}\text { Temp. } \\
\left({ }^{\circ} \mathrm{C}\right)\end{array}$ & $\begin{array}{l}\text { Conv. } \\
\text { (\%) }\end{array}$ & $\begin{array}{l}\text { Зaa/4aa } \\
\text { ratio }\end{array}$ \\
\hline 1 & {$\left[\mathrm{RuCl}_{2}(p \text {-cymene })\right]_{2}(0.5)$} & L1 (1) & 15 & 120 & $88^{\mathrm{b}}$ & $91 / 9$ \\
\hline 2 & {$\left[\mathrm{RuCl}_{2}(p \text {-cymene })\right]_{2}(0.25)$} & L1 (0.5) & 15 & 120 & 89 & $79 / 21$ \\
\hline 3 & {$\left[\mathrm{RuCl}_{2}(p \text {-cymene })\right]_{2}(0.5)$} & L6 (1) & 15 & 120 & $90^{\mathrm{b}}$ & $84 / 16$ \\
\hline 4 & {$\left[\mathrm{RuCl}_{2}(p \text {-cymene })\right]_{2}(0.5)$} & L8 (1) & 15 & 120 & $81^{b}$ & $79 / 21$ \\
\hline 5 & {$\left[\mathrm{RuCl}_{2}(p \text {-cymene })\right]_{2}(0.5)$} & L1 (1) & 50 & 120 & 89 & $85 / 15$ \\
\hline 6 & {$\left[\mathrm{RuCl}_{2}(p \text {-cymene })\right]_{2}(0.5)$} & L1 (1) & 100 & 120 & 100 & $100 / 0$ \\
\hline 7 & {$\left[\mathrm{RuCl}_{2}(p \text {-cymene })\right]_{2}(0.5)$} & $\mathbf{L} 1$ (1) & 100 & 100 & 100 & $95 / 5$ \\
\hline 8 & {$\left[\mathrm{RuCl}_{2}(p \text {-cymene })\right]_{2}(0.5)$} & L1 (1) & 100 & 80 & 76 & $87 / 10$ \\
\hline 9 & {$\left[\left[\mathrm{RuCl}_{2}(p \text {-cymene })\right]_{2}(0.25)\right.$} & L1 (0.5) & 100 & 120 & 97 & $95 / 5$ \\
\hline 10 & {$\left[\mathrm{RuCl}_{2}(p \text {-cymene })\right]_{2}(0.0625)$} & L1 (0.125) & 100 & 120 & 85 & $90 / 10$ \\
\hline 11 & {$\left[\mathrm{RuCl}_{2}(p \text {-cymene })\right]_{2}(0.0625)$} & L1 (0.125) & 100 & 120 & $98^{\mathrm{C}}$ & $92 / 8$ \\
\hline 12 & {$\left[\mathrm{RuCl}_{2}(p \text {-cymene })\right]_{2}(0.5)$} & L1 (1) & 100 & 120 & $68^{\mathrm{d}}$ & $98 / 2$ \\
\hline 13 & {$\left[\mathrm{RuCl}_{2}(p \text {-cymene })\right]_{2}(0.5)$} & L1 (1) & 100 & 120 & $100^{\mathrm{e}}$ & $96 / 4$ \\
\hline 14 & {$\left[\mathrm{RuCl}_{2}(p \text {-cymene })\right]_{2}(0.5)$} & no & 100 & 120 & 72 & $90 / 10$ \\
\hline 15 & $x^{2}$ & L1 (1) & 100 & 120 & 0 & - \\
\hline 16 & {$\left[\mathrm{RuCl}_{2}(p \text {-cymene })\right]_{2}(0.5)$} & no & 0 & 120 & 24 & $96 / 4$ \\
\hline
\end{tabular}

${ }^{\mathrm{a}}$ Aniline (1 mmol, 1 equiv.), benzyl alcohol (1.6 equiv.), ${ }^{t} \mathrm{BuOK}$ as a base, no solvent, GC conversion based on the amine, 3/4 GC ratio, reaction time : $15 \mathrm{~h}$, breaction time : $20 \mathrm{~h}$, ${ }^{\mathrm{c}}$ reaction time : $24 \mathrm{~h},{ }^{\mathrm{d}}$ water as solvent $(2 \mathrm{ml}),{ }^{\mathrm{e}}$ toluene as solvent $(1 \mathrm{ml})$

Based on this preliminary study, the scope of the reaction was investigated with substituted aromatic amines and benzylic alcohols applying our best experimental conditions (Table 2). Aniline reacted with para-substituted benzylic alcohols $\mathbf{2 b}$ and $\mathbf{2 c}$ to give the corresponding secondary benzylic anilines 3ab and 3ac in good yields and high selectivity (entries 2, 3). 4-Methylaniline (entries 4, 5) reacted similarly and provided excellent conversions and good isolated yields in 3ba and 3bc with benzyl alcohol 2a and isopropylbenzyl alcohol 2c. 
Table 2. Scope of the benzylation of anilines with benzylic alcohols

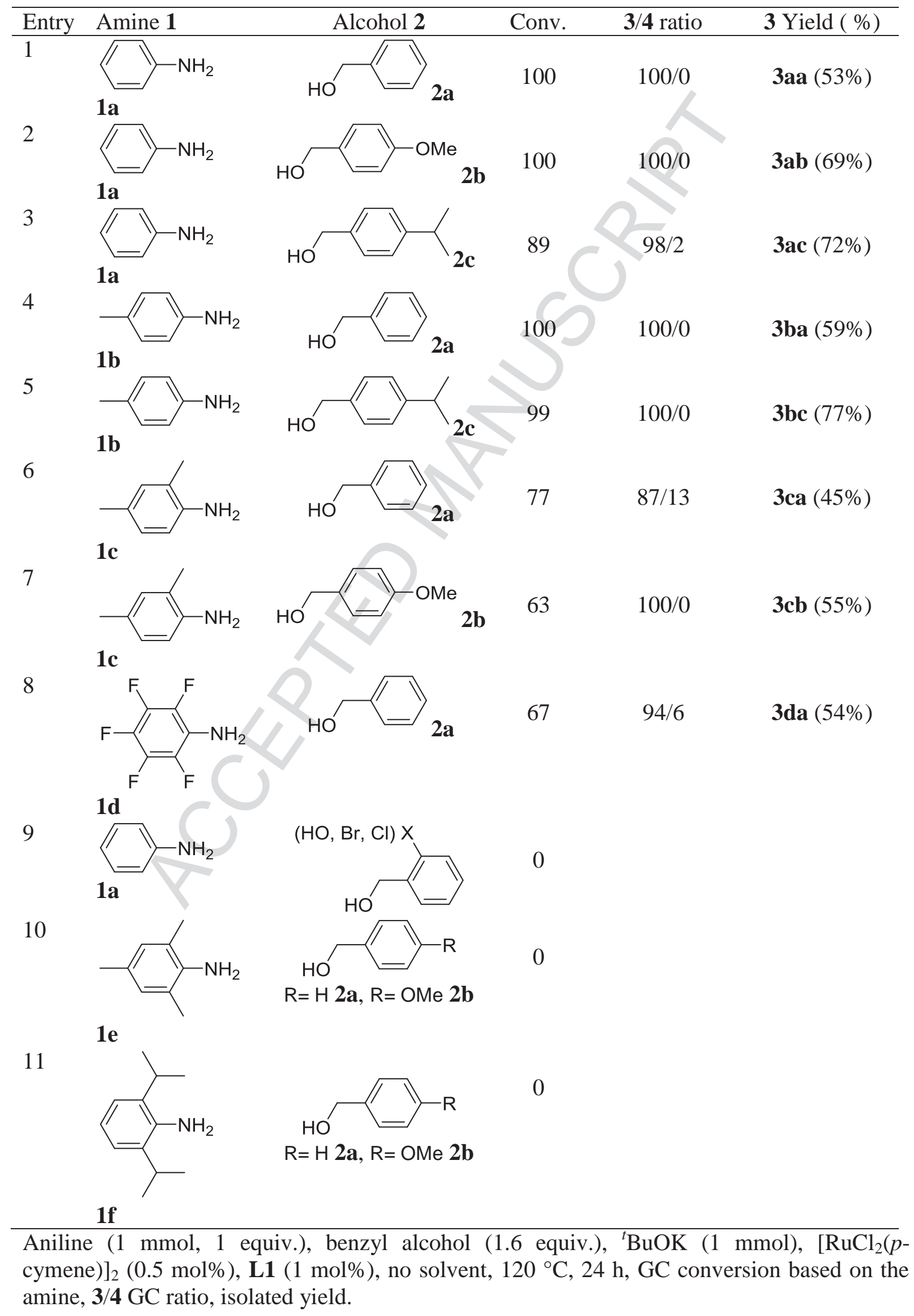


When 2,4-dimethylaniline 1c was used as substrate, the reaction became more difficult and conversions of 77 and 63\% only could be obtained with benzyl alcohol and 4-methoxybenzyl alcohol as respective partners after 24 h (entries 6, 7). 2,3,4,5,6-Pentafluoroaniline 1d reacted also with benzyl alcohol 2a to give the fluorinated aniline 3da in 67\% yield (entry 8). On the other hand, steric hindrance at the ortho-position of the aniline or the benzylic alcohol substrate

completely inhibited the reaction. More precisely, the ortho-disubstituted anilines $\mathbf{1 e}$ and $\mathbf{1 f}$ (entries 10,11) and ortho-monosubstituted hydroxy or halogenated benzylic alcohols (entry 9) were unreactive.

With the objective of preparing aniline derivatives of natural products, we showed that under similar reaction conditions, citronellol $\mathbf{2 d}$ reacted with aniline $\mathbf{1 a}$ and 4-methylaniline $\mathbf{1 b}$ to give the anilines 3ad and 3bd derived from terpene in 65 and 51\% yield, respectively (Eq. 1).
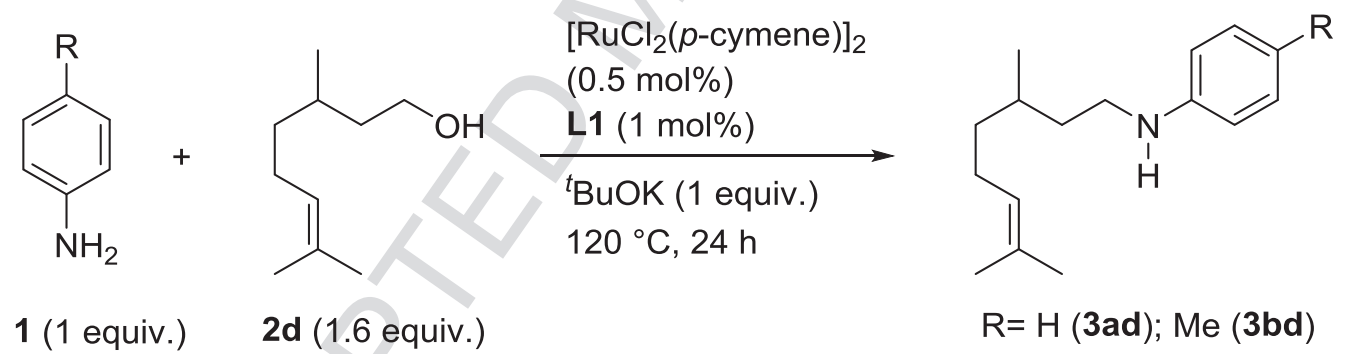

Equation 1. Terpenylation of anilines with citronellol

Alkylation of heteroaromatic amines such as aminoquinazolines, aminopyrimidines, aminoazoles or aminopyridine by alcohols have not been studied extensively in homogeneous catalysis and most of the successful results have been obtained with iridium catalysts [6, 33, 34]. With ruthenium catalysts, only a few examples of alkylation of 2-aminopyridine with alcohols have been recently reported with ruthenium complexes featuring tridentate (C,N,N) [24] ligand and cationic ruthenium(arene) complex equipped with a chelating pyridinecarbene ligand [27].

In the presence of our optimized catalytic system based on $\left[\operatorname{RuCl}_{2}(p \text {-cymene })\right]_{2}$ and the carbene sulfonate ligand derived from L1, the primary heteroaromatic 2-aminopyridine reacted readily with various alcohols to selectively give the $N$-monoalkylated secondary amines (Table 3). Primary benzylic alcohols gave excellent yields of $\mathrm{N}$-alkylated 2aminopyridines and the products 3ga, 3gc, and 3ge were isolated in 80, 75 and 60\% yield, respectively. Alkylation with the purely aliphatic 1-hexanol was also possible in satisfactory 
yield but with the secondary alcohols $\mathbf{2 g}$ the conversion was lower and required 30 equiv. of isopropanol to reach $75 \%$ yield.

Table 3. $N$-Alkylation of 2-aminopyridine $\mathbf{1 g}$

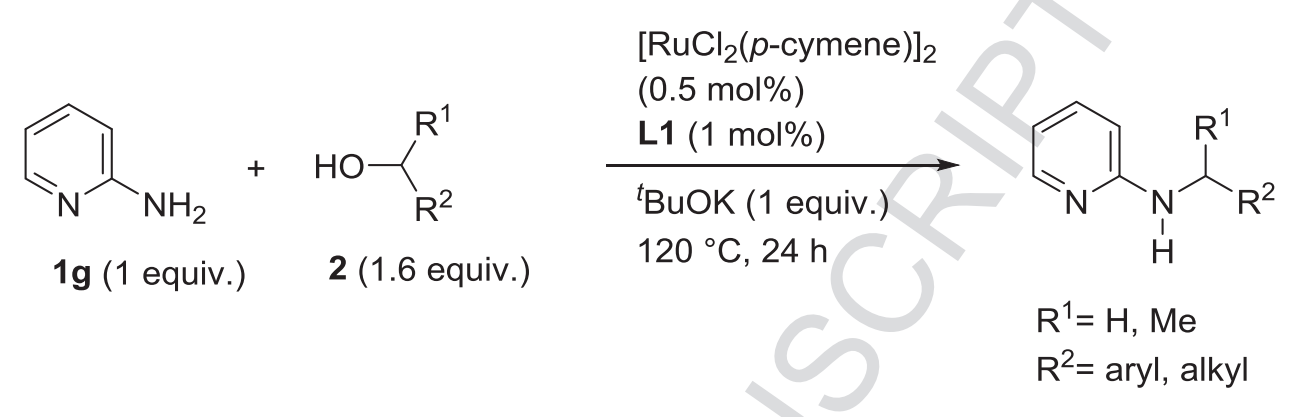

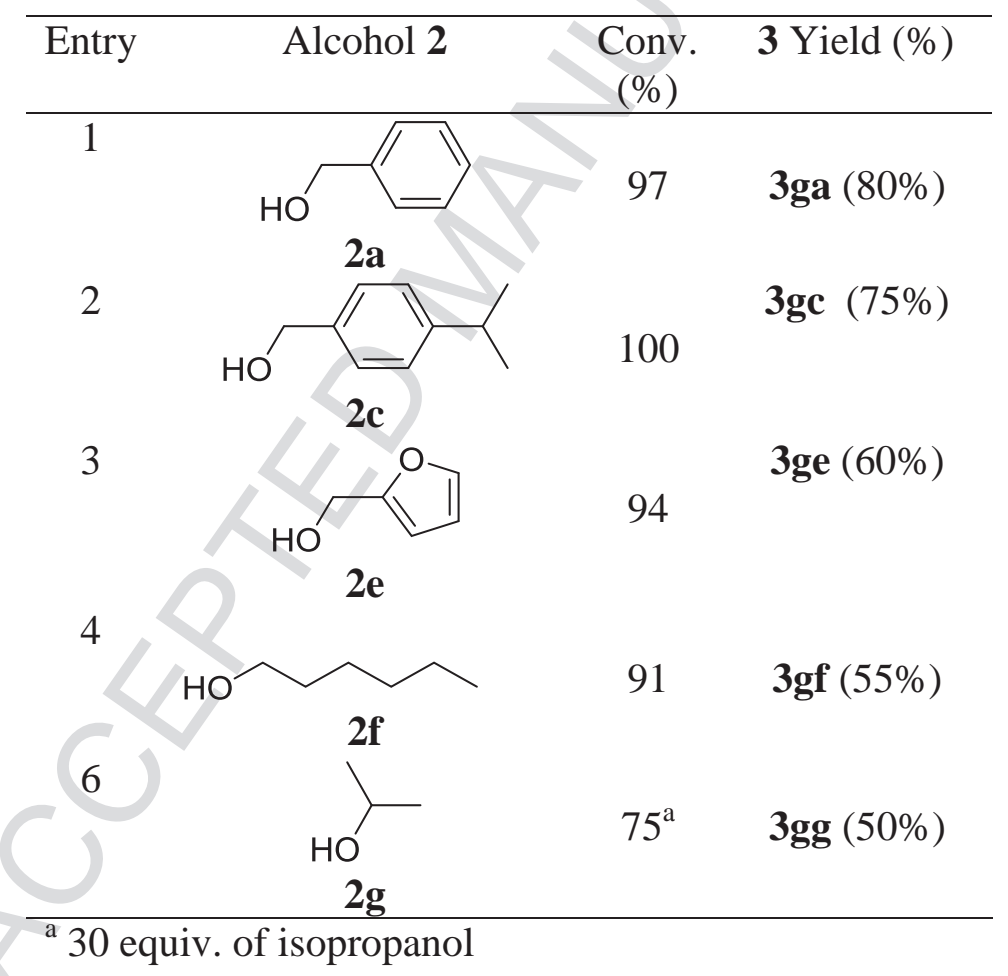

The ruthenium(carbene) complex $\mathrm{RuCl}_{2}$ (p-cymene)( $N, N^{\prime}$-bis(mesityl)imidazolylidene) featuring aryl substituents directly connected to the nitrogen atoms of the carbene is known to catalyze the formation of amides from alcohols and primary aliphatic amines including aniline at a lower extend, in the presence of $15 \mathrm{~mol} \%$ of ${ }^{t} \mathrm{BuOK}$ [28]. Recently, ruthenium complexes such as ( $N, N$-bis(benzyl)benzimidazolylidene)- and ( $N, N$-bis(isopropyl)benzimidazolylidene)$\mathrm{RuCl}_{2}$ (p-cymene) equipped with $N$-alkyl or/and $N$-benzyl NHC ligands with no chelating or hemilabile group on the NHC, have revealed good catalytic properties for the alkylation of anilines with various alcohols under neat conditions at $130{ }^{\circ} \mathrm{C}$ with $5 \mathrm{~mol} \%$ catalyst loading without additional base [35]. The presence of the sulfonate group in our NHC precursors does 
not seem to be essential in terms of reactivity, but contributes to promote the formation of amines rather than imines or amides. All these results show that the nature of the NHC carbene ligand is crucial for the ruthenium-catalyzed selective alkylation of anilines by alcohols with hydrogen borrowing processes.

However, at the moment, the most efficient catalytic systems for alkylation of aromatic amines operating under really mild conditions are based on iridium catalysts. They include reactions carried out in diglyme at $70{ }^{\circ} \mathrm{C}$ in the presence of ${ }^{t} \mathrm{BuOK}$ [16], a few examples at 50 ${ }^{\circ} \mathrm{C}$ in toluene/dichloromethane as solvent in the absence of an extra base [10], and even some scarce examples at room temperature in the presence of ${ }^{t} \mathrm{BuOK}$ under solvent-free conditions with 1 mol\% catalyst loading [20].

Attempts to generate ruthenium complexes with a chelating carbene sulfonate ligand from $\left[\mathrm{RuCl}_{2}(p \text {-cymene })\right]_{2}$ as metal source and a silver carbene prepared from $\mathbf{L 1}$ and $\mathrm{Ag}_{2} \mathrm{O}$ have failed but further studies are currently under investigation.

In summary, we have prepared a library of new benzimidazolium sulfonate salts from $N$-substituted benzimidazoles and 1,3-propanesultone. The catalytic systems generated in situ from these salts and $\left[\mathrm{RuCl}_{2}(p \text {-cymene })\right]_{2}$ in the presence of ${ }^{t} \mathrm{BuOK}$ are efficient in hydrogen borrowing processes and make possible the selective monoalkylation of primary aromatic amines such as substituted anilines and 2-aminopyridine with a variety of alcohols under neat conditions at $120^{\circ} \mathrm{C}$ with low catalyst loading. The scope and limitations mainly due to steric effects have been established.

\section{Acknowledgement}

The authors thank CNRS (France), the University of Rennes1 (France), and the University of Malatya (Turkey) for support. They also acknowledge the financial support of the Technological and Scientific Research Council of Turkey TUBİTAK- BOSPHORUS (France) [113Z605] for a grant to N.K. 


\section{References}

[1] Amines: Synthesis, Properties and Applications; S. A. Lawrence Ed.; Cambridge University Press, Cambridge, 2004.

[2] Q. Yang, Q. Wang, Z. Yu, Chem. Soc. Rev. 44 (2015) 2305-2329.

[3] R. Yamaguchi, K.-i Fujita, M. Zhu, Heterocycles 81 (2010) 1093-1140.

[4] G. Guillena, D. J. Ramon, M. Yus, Chem. Rev. 110 (2010) 1611-1641.

[5] G. E. Dobereiner, R. H. Crabtree, Chem. Rev. 110 (2010) 681-703.

[6] T. D. Nixon, M. K. Whittlesey, J. M. J. Williams, Dalton Trans. (2009) 753-762.

[7] K.-i. Fujita, Y. Enoki, R. Yamaguchi, Tetrahedron 64 (2008) 1943-1954.

[8] H. Aramoto, Y. Obara, Y. Ishii, J. Org. Chem. 74 (2009) 628-633.

[9] R. Kawahara, K.-i. Fujita, R. Yamaguchi, Adv. Synth. Catal. 353 (2011) 1161-1168.

[10] A. Bartoszewicz, R. Marcos, S. Sahoo, A. K. Inge, X. Zou, B. Martin-Matute, Chem. Eur. J. 18 (2012) 14510-14519.

[11] J. Norinder, A. Börner, ChemCatChem 3 (2011) 1407-1409.

[12] K.-T. Huh, Y. Tsuji, M. Kobayashi, F. Okuda, Y. Watanabe, Chem. Lett. (1988) 449452.

[13] S. G. Shim, C. H. Doh, B. W. Woo, H. S. Kim, K. T. Huh, W. H. Park, H. Lee, J. Mol. Catal. 62 (1990) L11-L15.

[14] C. S. Cho, B. T. Kim, H. J. Choi, T. J. Kim, S. C. Shim, Tetrahedron 59 (2003) 79978002.

[15] D. Wang, K. Zhao, C. Xu, H. Miao, Y. Ding, ACS Catal. 4 (2014) 3910-3918.

[16] S. Ruch, T. Irrgang, R. Kempe, Chem. Eur. J. 20 (2014) 13279-13285.

[17] K. D. Yuan, F. Jiang, Z. Sahli, M. Achard, T. Roisnel, C. Bruneau, Angew. Chem. Int. Ed. 51 (2012) 8876-8880.

[18] D. Gnanamgari, E. L. O. Sauer, N. D. Schley, C. Butler, C. D. Incarvito, R. H. Crabtree, Organometallics 28 (2009) 321-325.

[19] A. Pontes da Costa, M. Viciano, M. Sanau, S. Merino, J. Tejeda, E. Peris, B. Royo, Organometallics 27 (2008) 1305-1309.

[20] J.-Q. Li, P. G. Andersson, Chem. Commun. 49 (2013) 6131-6133.

[21] R. A. T. M. Abbenhuis, J. Boersma, G. van Koten, J. Org. Chem. 63 (1998) 42824290.

[22] S. Agrawal, M. Lenormand, B. Martin-Matute, Org. Lett. 14 (2012) 1456-1459.

[23] D. Weickmann, W. Frey, B. Plietker, Chem. Eur. J. 19 (2013) 2741-2748. 
[24] V. R. Jumde, L. Gonsalvi, A. Guerriero, M. Peruzzini, M. Taddei, Eur. J. Org. Chem. (2015) 1829-1833.

[25] S. Naskar, M. Bhattacharjee, Tetrahedron Lett. 48 (2007) 3367-3370.

[26] M. H. S. A. Hamid, C. L. Allen, G. W. Lamb, A. C. Maxwell, H. C. Maytum, A. J. A. Watson, J. M. J. Williams, J. Am. Chem. Soc. 131 (2009) 1766-1774.

[27] F. E. Fernandez, M. C. Puerta, P. Valerga, Organometallics 31 (2012) 6868-6879.

[28] Y. Zhang, C. Chen, S. C. Ghosh, Y. Li, S. H. Hong, Organometallics 29 (2010) 13741378.

[29] F. Jiang, M. Achard, C. Bruneau, Adv. Organometal. Chem. 62 (2014) 159-218.

[30] B. Cetinkaya, S. Demir, I. Özdemir, L. Toupet, D. Sémeril, C. Bruneau, P. H. Dixneuf, Chem. Eur. J. 2003, 9, 2323-2330.

[31] B. Gnanaprakasam, J. Zhang, D. Milstein, Angew. Chem. Int. Ed. 49 (2010) 14681471.

[32] A. B. Enyong, B. Moasser, J. Org. Chem. 79 (2014) 7553-7563.

[33] F. Li, L. Chen, Q. Kang, J. Cai, G. Zhu, New J. Chem. 37 (2013) 624-631.

[34] B. Blank, S. Michlik, R. Kempe, Adv. Synth. Catal. 351 (2009) 2903-2911.

[35] S. P. Shan, X. Xiaoke, B. Gnanaprakasam, T. T. Dang, B. Ramalingam, H. V. Huynh, A. M. Seayad, RSC Adv. 5 (2015) 4434-4442. 
Graphical Abstract

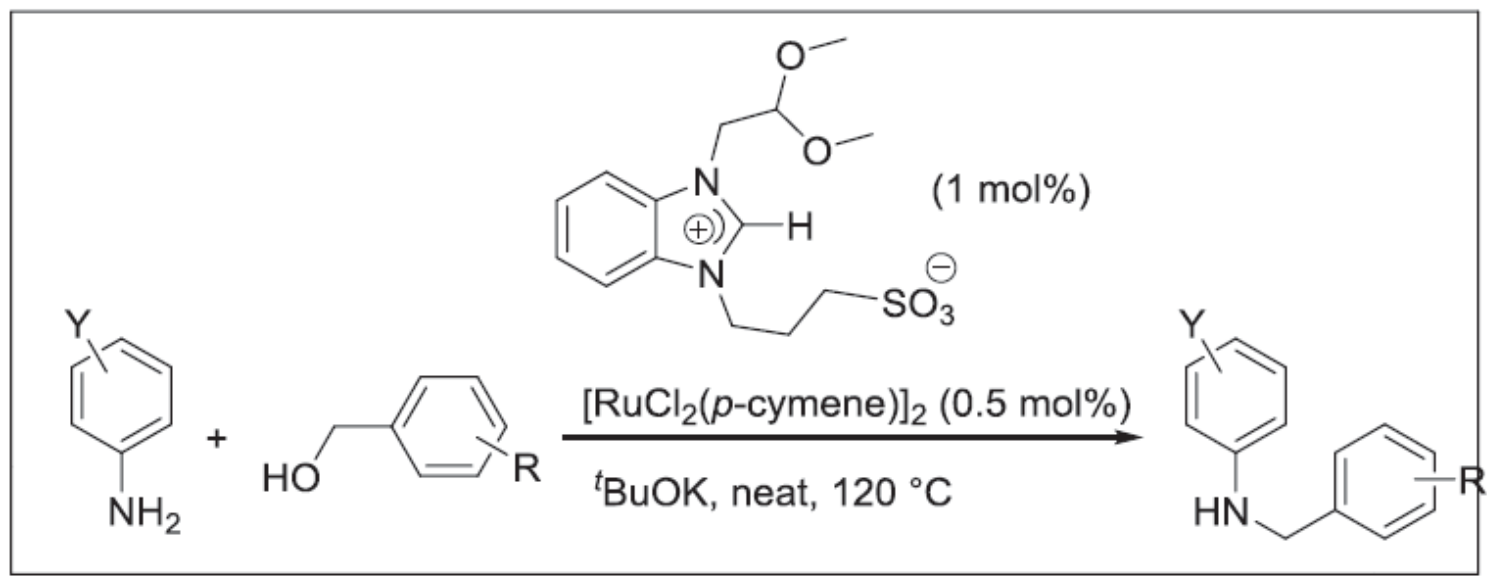




\section{Highlights}

- New benzimidazolium sulfonate salts

- In situ generated catalyst from $\left[\mathrm{RuCl}_{2}(p \text {-cymene })\right]_{2}$ and benzimidazolium sulfonate

- $\quad N$-alkylation of aromatic amines with alcohols via hydrogen borrowing process 